\title{
Vil fremtidens eldre være friskere?
}

\author{
Forskning på eldres helse viser sprikende funn. Et lengre liv er ikke nødvendigvis et lengre liv med god helse.
}

Vi lever lenger enn før. Men hvilken helsetilstand kan vi forvente oss i de ekstra årene $(1,2)$ ? Dette spørsmålet er det overraskende vanskelig å finne noe entydig svar på $(3,4)$.

Det er paradoksalt - fordi kunnskap om helsetrender hos eldre er viktig for utforming av helsepolitikk, for beregninger av fremtidige kostnader og behov innen helse- og omsorgssektoren og for planlegging og tilrettelegging av helsetjenester og behandling.

\section{Kompresjon,}

ekspansjon, ekvilibrium?

Forandringer i livsstil, bedre behandlingsmuligheter og bedre helsevesen kan påvirke fysiologien forbundet med aldring. Alderdommen kan arte seg på ulike måter.

I «kompresjonshypotesen» antas at økt levealder betyr flere år med god helse og fungering fordi sykdommene debuterer senere og typiske alderdomssvekkelser og sykdommer vil være komprimert til våre siste leveår (5).

I motsetning antar «ekspansjonshypotesen» at vi vil få flere leveår med sykdommer og dårlig helse fordi flere overlever og opplever å bli gamle med sykdommer som før hadde dødelig utgang tidlig i livet (6).

«Ekvilibriumhypotesen» foreslår noe midt imellom - endringer i kroniske sykdommers alvorlighetsgrad og progrediering vil holde samme tempo som endringer i dødelighet. Med et slikt scenario vil andelen år med alvorlige sykdommer og funksjonsnedsettelser i befolkningen stabiliseres eller reduseres, mens andelen år med moderate funksjonshemninger eller mindre alvorlige lidelser vil øke (7).

\section{Sprikende funn}

En gjennomgang av aldringsforskning fra hele verden, nylig publisert i The Lancet, viste sprikende funn. Den gir ikke konsistent støtte til noen av hypotesene, verken globalt eller i Europa (4).

Til støtte for kompresjonshypotesen pekes det på en observert nedgang i milde former for funksjonsnedsettelse hos eldre, til støtte for ekspansjonshypotesen tyder tallene på høyere forekomst av alvorligere tilstander (4). Dette er også konklusjonen i en oversiktsartikkel fra 2007: Health trends in the elderly population: getting better and getting worse (8).

\section{Helse - et mangslungent begrep}

En metodeforklaring på de sprikende funnene er at helse er et mangslungent begrep. Hvilke helseutfall og helseaspekter som blir inkludert i de forskjellige undersøkelsene varierer mye. Det er også store forskjeller i studiedesign, deltakelse og studiestørrelse (3), hvilket gjør at resultatene ofte ikke er sammenliknbare.

I tillegg er det slik at de aller eldste og sykeste langt sjeldnere enn andre deltar i befolkningsundersøkelser, noe som begrenser i hvilken grad funn fra publiserte undersøkelser er overførbare til å gjelde akkurat disse. Er det slik at den kunnskapen vi har i dag, i første rekke er betegnende for de friskeste av de eldste?

\section{Hva sier tallene?}

Helsestatus hos eldre defineres ofte som evnen til å klare seg på egen hånd i hverdagen (Activity of Daily Living, ADL).

\section{«Det skjer samfunns- endringer vi ikke uten videre kan forutse effekten av»}

Jo vanskeligere det er å utføre daglige gjøremål selv, desto dårligere helse uavhengig av andre helsevariabler, for eksempel kroniske lidelser.

Resultater fra den svenske H70-studien viser forbedring hos 75-åringer i evnen til å klare seg selv (ADL) fra 1970-årene og frem til 2000-årene (9). Også en annen svensk studie (SWEOLD) viste forbedringer i ADL-skår for personer over 77 år i perioden 1992-2011 (10). Tilsvarende forbedringer er rapportert for danske 90åringer (11). Imidlertid var det ingen forbedring i objektiv funksjonsevne, målt ved gripestyrke, reise-seg-fra-stol-setteseg-test og ganghastighet, for de danske 90-åringene (11).

I SWEOLD-studien var det nedgang i objektiv funksjonsevne, inkludert lungefunksjon, frem mot 2011, og det ble fremhevet at det nesten gjennomgående var forverringer i helsetilstand hos de eldre over tid (10). Analyser fra SWEOLD har også tidligere vist en nedgang i ADL-nivå fra 1990-årene og frem til 2000-årene (12).

Disse tilsynelatende paradoksale funnene inspirerte til en annen svensk landsrepresentativ analyse av eldre for perioden 1980-2005 som omfattet en rekke funksjonsmål (6). Her fant forskerne forbedringer på noen områder, som mobilitet, syn, daglige aktiviteter, og forverringer på andre områder, for eksempel for hørsel. Det ser ut til at forbedringene fant sted i 1980-årene og tidlig i 1990-årene, deretter snudde det og utviklet seg i mer ugunstig retning mot år 2005 .

Tilsvarende trender er også rapportert i Norge - først en forbedring i selvrapportert funksjonsnivå fra 1980-årene frem mot 2000-årene, og deretter en forverring mot $2008(13,14)$. Studier fra Sverige og Spania tyder på at denne nedgangen i funksjonsnivå i 2000-årene spesielt ser ut til å gjelde eldre kvinner $(15,16)$.

Det er forskjeller mellom land, og det skjer samfunnsendringer vi ikke uten videre kan forutse effekten av. Ett eksempel er den $ø$ kte forekomsten av overvekt. I USA er det i flere studier funnet forbedringer i mobilitet hos eldre (17), samtidig som prognoser tyder på at overvekt i befolkningen kan føre til ikke bare redusert forventet levealder, men også til flere leveår med sykdommer og dårlig helse.

\section{Hvordan kan vi få svaret?}

I de fleste studier om helse og sosiale forhold hos eldre har man til nå brukt selvrapportering som metode for å innhente data.

Heldigvis er det større bevissthet og ønske blant forskere om å harmonisere undersøkelsene. Ved å bruke like mål og målemetoder i undersøkelser i ulike utvalg vil resultatene kunne sammenliknes over tid, mellom grupper (eldre og yngre, hjemmeboende og sykehjemspasienter) og mellom land. Det inkluderes i større grad enn tidligere objektive tester av funksjonsnivået hos eldre.

Foreløpig ser det ikke ut til at vi kan ha forventninger om bedre helse hos eldre i fremtiden - et lengre liv er altså ikke nødvendigvis ensbetydende med et lengre liv med god helse. Men tallene er usikre. Nye undersøkelser er nødvendig for å få økt kunnskap om helsetrender hos eldre. I Norge er vi kommet kortere innen aldersforskning enn de andre skandinaviske land.

\section{Ellen Melbye Langballe} eml@aldringoghelse.no

Bjørn Heine Strand

Ellen Melbye Langballe (f. 1971) er ph.d., fagsjef og seniorforsker ved Nasjonal kompetansetjeneste for aldring og helse, Sykehuset Vestfold. Forfatter har fylt ut ICMJE-skjemaet og oppgir ingen interessekonflikter. 
Bjørn Heine Strand (f. 1974) er ph.d. og seniorforsker. Han arbeider ved Nasjonalt folkehelseinstitutt, Universitetet i Oslo og Nasjonal kompetansetjeneste for aldring og helse.

Forfatter har fylt ut ICMJE-skjemaet og oppgir ingen interessekonflikter.

\section{Litteratur}

1. Vaupel JW. Biodemography of human ageing. Nature 2010; 464: 536-42

2. Brunborg H. Increasing life expectency and the growing elderly population. Norsk Epidemiologi 2012: 22: 75-83

3. Christensen K, Doblhammer G, Rau R et al. Ageing populations: the challenges ahead. Lancet 2009. 374: 1196-208.

4. Chatterji S, Byles J, Cutler D et al. Health, functioning, and disability in older adults - present status and future implications. Lancet 2014. E-publisert 6.11 .

5. Sierra F, Hadley E, Suzman R et al. Prospects for life span extension. Annu Rev Med 2009. 60: 457-69.
6. Parker M, Schon PA, Lagergren MA et al. Functional ability in the elderly Swedish population from 1980 to 2005. Eur J Ageing 2008; 5: 299-309.

7. Manton KG. Changing concepts of morbidity and mortality in the elderly population. Milbank Mem Fund Q Health Soc 1982; 60: 183-244.

8. Parker MG, Thorslund M. Health trends in the elderly population: getting better and getting worse. Gerontologist 2007; 47: $150-8$

9. Falk $\mathrm{H}$, Johansson L, Ostling $S$ et al. Functional disability and ability 75-year-olds: a comparison of two Swedish cohorts born 30 years apart. Age Ageing 2014; 43: 636-41.

10. Fors $\mathrm{S}$, Lennartsson $\mathrm{C}$, Agahi $\mathrm{N}$ et al. Intervjustudie om de allra äldstas levnadsvillkor. Aldre har fått fler hälsoproblem, men klarar vardagen bättre. Läkartidningen 2013; 110: 1403-5.

11. Christensen K. Thinggaard M, Oksuzyan A et al. Physical and cognitive functioning of people older than 90 years: a comparison of two Danish cohorts born 10 years apart. Lancet 2013; 382: 1507-13.

12. Parker MG, Ahacic K, Thorslund M. Health changes among Swedish oldest old: prevalence rates from 1992 and 2002 show increasing health problems. J Gerontol A Biol Sci Med Sci 2005; 60: $1351-5$.

13. Mørk E. Seniorer i Norge 2010. Oslo: Statistisk sentralbyrå, 2011
14. Moe JO, Hagen TP. Trends and variation in mild disability and functional limitations among older adults in Norway, 1986-2008. Eur J Ageing 2011; 8: $49-61$

15. Sjölund BM, Wimo A, Qiu C et al. Time trends in prevalence of activities of daily living (ADL) disability and survival: comparing two populations laged 78+ years) living in a rural area in Sweden. Arch Gerontol Geriatr 2014; 58: $370-5$.

16. Sagardui-Villamor J, Guallar-Castillón P, GarcíaFerruelo $\mathrm{M}$ et al. Trends in disability and disabilityfree life expectancy among elderly people in Spain: 1986-1999. J Gerontol A Biol Sci Med Sci 2005; 60 : 1028-34.

17. Freedman VA, Martin LG, Schoeni RF. Recent trends in disability and functioning among older adults in the United States: a systematic review. JAMA 2002; 288: 3137-46.

Mottatt 18.12. 2014, første revisjon innsendt 22.12 2014, godkjent 2.1. 2015. Redaktør: Erlend Hem.

Publisert først på nett. 